ISSN 0258-7122 (Print), 2408-8293 (Online)

Bangladesh J. Agril. Res. 41(1): 85-90, March 2016

\title{
RESPONSES OF GARLIC TO ZINC, COPPER, BORON AND MOLYBDENUM APPLICATION IN GREY TERRACE SOIL OF AMNURA SOIL SERIES
}

\author{
M. N. YOUSUF ${ }^{1}$, M. M. HASAN ${ }^{2}$, S. BRAHMA ${ }^{3}$ \\ DEEDER SUlTANA ${ }^{4}$ AND A. H. M. FAZLUL KABIR ${ }^{5}$
}

\begin{abstract}
A field experiment was conducted at the Spices Research Centre, Shibgonj, Bogra, Bangladesh during rabi (winter) seasons of 2008-09 and 2009-10 to determine the requirement of $\mathrm{Zn}, \mathrm{Cu}, \mathrm{B}$ and Mo of garlic (BARI Garlic 2) along with a blanket dose of cowdung $5 \mathrm{t}, 100 \mathrm{~kg} \mathrm{~N}, 40 \mathrm{~kg} \mathrm{P}, 100 \mathrm{~kg} \mathrm{~K}$ and $30 \mathrm{~kg} \mathrm{~S} / \mathrm{ha}$ for achieving satisfactory bulb yield of this crop. Different levels of zinc $(0,1.0$, $1.5,3.0$ and $4.5 \mathrm{~kg} / \mathrm{ha})$, copper $(0,0.5,1.0$ and $1.5 \mathrm{~kg} / \mathrm{ha})$, boron $(0,1.0,2.0$ and $3.0 \mathrm{~kg} / \mathrm{ha})$ and molybdenum $(0,0.5$ and $1.0 \mathrm{~kg} / \mathrm{ha})$ were distributed in the plot. The experiment was tested in randomized complete block design with three replications. The positive impact of application of those nutrients plant height, number of leaves per plant, cloves per bulb, diameter and weight of bulb and yield of garlic up to a moderate level of $\mathrm{Zn}_{3.0} \mathrm{Cu}_{1.0} \mathrm{~B}_{3.0} \mathrm{Mo}_{1.0} \mathrm{~kg} / \mathrm{ha}$. The highest bulb yield (4.87 t/ha in 2008-09 and 6.6 t/ha in 2009-10) was obtained from $\mathrm{Zn}_{3.0} \mathrm{Cu}_{1.0} \mathrm{~B}_{3.0} \mathrm{Mo}_{1.0} \mathrm{~kg} / \mathrm{ha}$ and yield was declined with higher dose of these elements except Mo. The fertilizer treatment $\mathrm{Zn}_{3.0} \mathrm{Cu}_{1.0} \mathrm{~B}_{3.0} \mathrm{Mo}_{1.0} \mathrm{~kg} / \mathrm{ha}$ was observed to be the best suitable dose for garlic production on Grey Terrace Soil of Amnura Soil Series under AEZ-25 (Level Barind Tract) of Bangladesh.
\end{abstract}

Keywords: Garlic, growth, bulb yield, Zinc, Copper, Boron and Molybdenum.

\section{Introduction}

Garlic (Allium sativum L.) is the second most widely used spices crop of the cultivated Allium group, next to onion in the world (Purseglove, 1987). It has a characteristic pungent, spicy flavor that mellows and sweetens considerably with cooking (Katzer, 2005). The cloves are used as seed, for consumption (raw or cooked), and for medicinal purposes. It has higher nutritive value than other bulb crops as it is rich in proteins, $\mathrm{P}, \mathrm{K}, \mathrm{Ca}, \mathrm{Mg}$ and carbohydrates and hence also finds medicinal usages especially in treating intestinal diseases, heart disease including atherosclerosis, high cholesterol, high blood pressure, and cancer (Balch, 2000; Durak et al., 2004). Most of the researches on nutrition of garlic limit the recommendation for major nutrients like $\mathrm{N}, \mathrm{P}$ and $\mathrm{K}$ but micronutrients also play a vital role in deciding the growth and development of plants. Significant effects were noticed on yield and yield attributes of garlic when micronutrients were used (Chanchan et al., 2013). Gupta and Ganeshe (2000)

${ }^{1}$ Regional Spices Research Centre, Bangladesh Agricultural Research Institute (BARI), Gazipur, ${ }^{2 \& 3}$ Spices Research Centre, BARI, Shibgonj, Bogra, ${ }^{4 \& 5}$ Senior Scientific Officer, Planning and Evaluation Wing, BARI, Gazipur, Bangladesh. 
revealed that zinc sulfate $(25 \mathrm{~kg} / \mathrm{ha})+$ borax $(10 \mathrm{~kg} / \mathrm{ha})$ promoted yield marginally by $45.8 \mathrm{~kg} / \mathrm{ha}$ in garlic over the control (recommended dose of $\mathrm{N}, \mathrm{P}$ and K. Application of boron at $0.1 \%+$ sodiummolybdate at $0.05 \%$ (w/v) recorded the highest healthy bulb yield and reduced premature field-sprouting of Cloves(Selvaraj et al., 2002). Srivastava et al. (2005) reported that boric acid at $0.1 \%$ and zinc sulfate at $0.4 \%$ resulted in maximum bulb yield and total soluble solids. Jermsiri et al. (1995) reported that applying borax to garlic increased the yield by $24-40 \%$. The lack of experimental evidence on the response of garlic to the micronutrients necessitated the assessment of the efficacy of $\mathrm{Zn}, \mathrm{Cu}, \mathrm{B}$ and Mo in order to achieve its productivity potential. The present experiment was, therefore undertaken to assess the response of $\mathrm{Zn}, \mathrm{Cu}, \mathrm{B}$ and Mo on growth and yield of garlic in presence of N, P, K and S in Grey Terrace Soil of Amnura Soil Series under AEZ-25 (Level Barind Tract) of Bangladesh.

\section{Materials and Method}

The experiment was carried out at the Spices Research Centre, Shibgonj, Bogra, Bangladesh on Grey Terrace Soil of Amnura Soil Series under AEZ-25 (Level Barind Tract) during rabi (winter) season of two consecutive years i.e., 20082009 and 2009-2010. A description of some physical and chemical properties of experimental soil collected from a depth of $0-15 \mathrm{~cm}$ prior to application of fertilizers is presented in Table 1. The experiment was set up in Randomized Complete Block (RCB) design with 14 treatment combinations having three replications. The treatments included 5 levels of zinc $(0,1.0,1.5,3.0$ and 4.5 $\mathrm{kg} / \mathrm{ha}$ as zinc oxide), 4 levels of copper $(0,0.5,1.0$ and $1.5 \mathrm{~kg} / \mathrm{ha}$ as copper sulfate), 4 levels of boron (0, 1.0, 2.0 and 3.0 t/ha as boric acid) and 3 levels of molybdenum $(0,0.5$ and $1.0 \mathrm{~kg} / \mathrm{ha}$ as sodium molybdate). A blanket dose of cowdung $5 \mathrm{t} / \mathrm{ha}, 100 \mathrm{~kg} \mathrm{~N} / \mathrm{ha}$ as Urea, $40 \mathrm{~kg}$ P/ha from TSP, $100 \mathrm{~kg} \mathrm{~K} / \mathrm{ha}$ as MOP and $30 \mathrm{~kg}$ S/ha as Gypsum were applied to each treatment. The whole amount of cowdung, TSP, MOP, Gypsum, Zinc oxide, Boric acid, Copper sulfate, Sodium molybdate applied as basal dose and $1 / 3^{\text {rd }}$ urea was applied in two equal installments at $3^{\text {rd }}$ and $6^{\text {th }}$ week after transplanting. The cloves of garlic cv. BARI Garlic-2 were planted on 30 October of both years in $3 \mathrm{~m} \mathrm{x} 3 \mathrm{~m}$ plot at $15 \mathrm{~cm} \times 10 \mathrm{~cm}$ spacing. The first irrigation was given immediately after planting. The intercultural operations (four irrigations, three weeding and Rovral + Ridomil Gold/Antracol + Gain spray every 10 days interval for controlling diseases and insects pest) were done in the cropping period. The observations on growth parameters like plant height and number of leaves were recorded at 100 days after planting (DAP). The bulb of garlic was harvested on 27 March, 2009 and 30 March, 2010 at it was fully matured. Ten bulbs were selected randomly from each treatment for counting number of cloves and recorded bulb size and single bulb weight. The total weight of bulb per plot was recorded to obtain the yield per hectare. The data were subjected to statistical analysis by using 
MSTAT-C software to find out the significance of variation resulting from the experimental treatments. The difference between the treatment means were judged by Duncan's Multiple Range Test (DMRT) at 5\% level of probability according to Gomez and Gomez (1984).

Table 1. Soil properties of the experimental site during 2008-09 and 2009-10

\begin{tabular}{|c|c|c|c|c|c|c|c|c|c|c|c|c|c|}
\hline \multirow[t]{2}{*}{ Texture } & \multirow[t]{2}{*}{$\mathrm{pH}$} & \multirow{2}{*}{$\begin{array}{c}\mathrm{OM} \\
\%\end{array}$} & $\mathrm{Ca}$ & $\mathrm{Mg}$ & K & \multirow{2}{*}{$\begin{array}{c}\text { Total } \\
\mathrm{N}\end{array}$} & \multirow{2}{*}{$\mathrm{P}$} & \multirow[t]{2}{*}{ S } & \multirow[t]{2}{*}{ B } & \multirow{2}{*}{\multicolumn{2}{|c|}{\begin{tabular}{|c|c|}
$\mathrm{Zn}$ & $\mathrm{Cu}$ \\
$(\mu \mathrm{g} / \mathrm{g}$ soil $)$
\end{tabular}}} & \multirow[t]{2}{*}{$\mathrm{Mn}$} & \multirow[t]{2}{*}{ Mo } \\
\hline & & & \multicolumn{3}{|c|}{ (meq/100g soil) } & & & & & & & & \\
\hline \multicolumn{14}{|c|}{ 2008-09 } \\
\hline $\begin{array}{l}\text { Sandy } \\
\text { loam }\end{array}$ & 5.4 & 1.00 & 1.6 & 0.71 & 0.30 & 0.053 & 14 & 15.1 & 0.12 & 0.91 & 0.08 & 2.0 & 0.05 \\
\hline \multicolumn{14}{|c|}{ 2009-10 } \\
\hline Clay loam & 5.7 & 0.89 & 1.9 & 0.77 & 0.56 & 0.043 & 13 & 15.5 & 0.09 & 0.96 & 0.06 & 2.0 & 0.05 \\
\hline $\begin{array}{l}\text { Critical } \\
\text { level }\end{array}$ & - & - & 2.0 & 0.5 & 0.12 & - & 07 & 10 & 0.2 & 0.6 & 0.2 & 1.0 & 0.1 \\
\hline
\end{tabular}

\section{Results and Discussion}

Plant height recorded at 100 days after planting (DAP) reveled that no significant variations were observed in the year 2008-09 and significant variations in the year 2009-10 among different treatments (Table 2). The tallest plant $(25.6 \mathrm{~cm}$ and $60.43 \mathrm{~cm}$ ) was recorded in treatment $\mathrm{Zn}_{3.0} \mathrm{Cu}_{1.0} \mathrm{~B}_{3.0} \mathrm{Mo}_{1.0} \mathrm{~kg} / \mathrm{ha}$ in both the years (2008-09 and 2009-10, respectively), while smallest plant was recorded in control. Number of leaves per plant differed significantly due to application of micronutrients (Table 2) revealed that maximum number of leaves per plant $(8.47$ and 8.9) were found with the application of $\mathrm{Zn}_{3.0} \mathrm{Cu}_{1.0} \mathrm{~B}_{3.0} \mathrm{Mo}_{1.0} \mathrm{~kg} / \mathrm{ha}$ in both the years (2008-09 and 2009-10, respectively). Chanchan et al. (2013) also obtained similar results. This was probably due to the availability of more nutriment elements to plant at which could produce more leaves resulting more photosynthetic production. The bulb size i.e., bulb length and bulb diameter was significantly influenced by different levels of micronutrients (Table 2). The Longest bulb $(4.53 \mathrm{~cm}$ and $7.77 \mathrm{~cm})$ were found with the application of $\mathrm{Zn}_{3.0} \mathrm{Cu}_{1.0} \mathrm{~B}_{3.0} \mathrm{Mo}_{1.0} \mathrm{~kg} / \mathrm{ha}$, while the smallest bulb in control in the year 2008-09 and 2009-10, respectively. The maximum bulb diameter $(4.9 \mathrm{~cm})$ was noticed with the application of $\mathrm{Zn}_{3.0} \mathrm{Cu}_{1.0} \mathrm{~B}_{2.0} \mathrm{Mo}_{0.5} \mathrm{~kg} / \mathrm{ha}$ in the year 2008-09 and the maximum bulb diameter $(7.2 \mathrm{~cm})$ was found with the application of $\mathrm{Zn}_{3.0} \mathrm{Cu}_{1.0} \mathrm{~B}_{3.0} \mathrm{Mo}_{1.0} \mathrm{~kg} / \mathrm{ha}$ and $\mathrm{Zn}_{3.0} \mathrm{Cu}_{1.0} \mathrm{~B}_{2.0} \mathrm{Mo}_{0.5} \mathrm{~kg} / \mathrm{ha}$ in the year 2009-10, while the minimum bulb diameter were found in control both the years. Bulb size seems to be the most important component closely related with yield per hectare. The favorable effects of micronutrients might be attributed due to its involvement in cell division and cell expansion, improve physiological activities like photosynthesis during food manufactured by the plant and translocate in the bulb. 
Table 2. Influence of micronutrients on vegetative growth of garlic

\begin{tabular}{|c|c|c|c|c|c|c|c|c|}
\hline \multirow{3}{*}{ Treatment } & \multirow{2}{*}{\multicolumn{2}{|c|}{$\begin{array}{l}\text { Plant height } \\
\text { (cm) }\end{array}$}} & \multirow{2}{*}{\multicolumn{2}{|c|}{$\begin{array}{c}\text { No. of leaves } \\
\text { per plant }\end{array}$}} & \multicolumn{4}{|c|}{ Bulb size } \\
\hline & & & & & \multicolumn{2}{|c|}{ Bulb length $(\mathrm{cm})$} & \multicolumn{2}{|c|}{$\begin{array}{l}\text { Bulb diameter } \\
\qquad(\mathrm{cm})\end{array}$} \\
\hline & $\begin{array}{c}2008- \\
09\end{array}$ & $\begin{array}{c}2009- \\
10\end{array}$ & $\begin{array}{c}2008- \\
09\end{array}$ & $2009-10$ & $\begin{array}{c}2008- \\
09\end{array}$ & $\begin{array}{c}2009- \\
10\end{array}$ & 2008-09 & $2009-10$ \\
\hline $\mathrm{Zn}_{0} \mathrm{Cu}_{1.0} \mathrm{~B}_{2.0} \mathrm{Mo}_{1.0}$ & 23.33 & $49.50 \mathrm{~b}$ & $7.8 \mathrm{ab}$ & $7.83 \mathrm{~d}$ & $3.03 \mathrm{f}$ & $5.03 \mathrm{de}$ & $4.10 \mathrm{bc}$ & $5.30 \mathrm{~cd}$ \\
\hline $\mathrm{Zn}_{1.0} \mathrm{Cu}_{1.0} \mathrm{~B}_{2.0} \mathrm{Mo}_{1.0}$ & 25.13 & $55.83 \mathrm{a}$ & $7.73 b$ & $8.33 \mathrm{bc}$ & $3.47 \mathrm{def}$ & $5.87 \mathrm{~b}-\mathrm{e}$ & $4.40 \mathrm{ab}$ & $5.67 \mathrm{a}-\mathrm{d}$ \\
\hline $\mathrm{Zn}_{1.5} \mathrm{Cu}_{1.0} \mathrm{~B}_{2.0} \mathrm{Mo}_{1.0}$ & 23.67 & $58.77 \mathrm{a}$ & $7.87 \mathrm{ab}$ & $8.30 \mathrm{bcd}$ & $3.63 c-f$ & $5.87 \mathrm{~b}-\mathrm{e}$ & $4.40 \mathrm{ab}$ & $6.13 a b c$ \\
\hline $\mathrm{Zn}_{3.0} \mathrm{Cu}_{1.0} \mathrm{~B}_{2.0} \mathrm{Mo}_{1.0}$ & 23.53 & $59.27 \mathrm{a}$ & 7.90ab & $8.50 \mathrm{abc}$ & $4.33 \mathrm{ab}$ & $6.97 \mathrm{abc}$ & $4.73 \mathrm{ab}$ & $7.03 \mathrm{ab}$ \\
\hline $\mathrm{Zn}_{4.5} \mathrm{Cu}_{1.0} \mathrm{~B}_{2.0} \mathrm{Mo}_{1.0}$ & 23.20 & $59.20 \mathrm{a}$ & $7.07 \mathrm{c}$ & $8.47 \mathrm{abc}$ & $4.10 \mathrm{a}-\mathrm{d}$ & $6.77 \mathrm{abc}$ & $4.40 \mathrm{ab}$ & $7.00 \mathrm{abc}$ \\
\hline $\mathrm{Zn}_{3.0} \mathrm{Cu}_{0} \mathrm{~B}_{2.0} \mathrm{Mo}_{1.0}$ & 25.00 & $58.13 \mathrm{a}$ & $8.07 \mathrm{ab}$ & $8.07 \mathrm{~cd}$ & $3.63 \mathrm{c}-\mathrm{f}$ & $6.13 a-d$ & $3.40 \mathrm{~d}$ & $6.40 \mathrm{abc}$ \\
\hline $\mathrm{Zn}_{3.0} \mathrm{Cu}_{0.5} \mathrm{~B}_{2.0} \mathrm{Mo}_{1.0}$ & 24.67 & $58.13 \mathrm{a}$ & 7.93ab & $8.40 \mathrm{bc}$ & $4.20 \mathrm{abc}$ & $6.30 \mathrm{a}-\mathrm{d}$ & $4.723 \mathrm{ab}$ & $6.63 \mathrm{abc}$ \\
\hline $\mathrm{Zn}_{3.0} \mathrm{Cu}_{1.5} \mathrm{~B}_{2.0} \mathrm{Mo}_{1.0}$ & 24.30 & $60.27 \mathrm{a}$ & $8.13 \mathrm{ab}$ & $8.60 \mathrm{ab}$ & $4.47 \mathrm{a}$ & $7.60 \mathrm{a}$ & $4.87 \mathrm{a}$ & $6.47 \mathrm{abc}$ \\
\hline $\mathrm{Zn}_{3.0} \mathrm{Cu}_{1.0} \mathrm{~B}_{0} \mathrm{Mo}_{1.0}$ & 22.60 & $56.10 \mathrm{a}$ & $8.07 \mathrm{ab}$ & $8.23 \mathrm{bcd}$ & $3.13 \mathrm{ef}$ & $5.63 \mathrm{cde}$ & $3.20 \mathrm{~d}$ & $5.67 \mathrm{a}-\mathrm{d}$ \\
\hline $\mathrm{Zn}_{3.0} \mathrm{Cu}_{1.0} \mathrm{~B}_{1.0} \mathrm{Mo}_{1.0}$ & 23.00 & $60.43 a$ & $8.07 \mathrm{ab}$ & $8.60 \mathrm{ab}$ & $4.00 \mathrm{a}-\mathrm{d}$ & $6.87 \mathrm{abc}$ & $4.80 \mathrm{ab}$ & $6.47 \mathrm{abc}$ \\
\hline $\mathrm{Zn}_{3.0} \mathrm{Cu}_{1.0} \mathrm{~B}_{3.0} \mathrm{Mo}_{1.0}$ & 25.60 & $61.30 \mathrm{a}$ & $8.47 \mathrm{a}$ & $8.90 \mathrm{a}$ & $4.53 \mathrm{a}$ & $7.77 \mathrm{a}$ & $4.80 \mathrm{ab}$ & $7.20 \mathrm{a}$ \\
\hline $\mathrm{Zn}_{3.0} \mathrm{Cu}_{1.0} \mathrm{~B}_{2.0} \mathrm{Mo}_{0}$ & 22.73 & $58.03 \mathrm{a}$ & $7.87 \mathrm{ab}$ & $8.20 \mathrm{bcd}$ & $3.17 \mathrm{ef}$ & $6.27 a-d$ & $3.57 \mathrm{ed}$ & $5.40 \mathrm{bcd}$ \\
\hline $\mathrm{Zn}_{3.0} \mathrm{Cu}_{1.0} \mathrm{~B}_{2.0} \mathrm{Mo}_{0.5}$ & 23.27 & $59.97 \mathrm{a}$ & $8.17 \mathrm{ab}$ & $8.20 \mathrm{bcd}$ & $3.73 b-e$ & $7.37 \mathrm{ab}$ & $4.90 \mathrm{a}$ & $7.20 \mathrm{a}$ \\
\hline $\mathrm{Zn}_{0} \mathrm{Cu}_{0} \mathrm{~B}_{0} \mathrm{Mo}_{0}$ & 22.47 & $34.87 \mathrm{c}$ & $7.73 b$ & $7.13 \mathrm{e}$ & $1.80 \mathrm{~g}$ & $4.43 \mathrm{e}$ & $2.37 \mathrm{e}$ & $4.23 \mathrm{~d}$ \\
\hline CV $(\%)$ & 6.36 & 6.12 & 4.63 & 2.98 & 9.67 & 13.25 & 8.72 & 13.85 \\
\hline
\end{tabular}

Treatment means having common letter(s) are not significantly different from each other at $5 \%$ level of probability by DMRT.

Data presented in Table 3, indicated that different levels of micronutrients had significant variations on number of cloves per bulb. Maximum number of cloves per bulb (40.37) was observed with the application of $\mathrm{Zn}_{3.0} \mathrm{Cu}_{1.0} \mathrm{~B}_{3.0} \mathrm{Mo}_{1.0} \mathrm{~kg} / \mathrm{ha}$ and $\mathrm{Zn}_{3.0} \mathrm{Cu}_{1.0} \mathrm{~B}_{2.0} \mathrm{Mo}_{0.5} \mathrm{~kg} / \mathrm{ha}$ in the year 2008-09 and in year 2009-10 the maximum number of cloves per bulb (45.37) was recorded with $\mathrm{Zn}_{3.0} \mathrm{Cu}_{1.0} \mathrm{~B}_{3.0} \mathrm{Mo}_{1.0} \mathrm{~kg} / \mathrm{ha}$. The minimum number of cloves per bulb (20.07 and 21.13) was noticed with control in both years. These parameters could be used as indicators of improving yield potential in garlic. These results are in accordance with the research findings of (Selvaraj et al., 2002 and Srivastava et al., 2005). The effect of different levels of applied micronutrient on single bulb weight of garlic was statistically significant (Table 3 ). The maximum weight of single bulb (28.93 $\mathrm{g}$ in 2008-09 and 41.70 $\mathrm{g}$ in 2009-10) was recorded from $\mathrm{Zn}_{3.0} \mathrm{Cu}_{1.0} \mathrm{~B}_{3.0} \mathrm{Mo}_{1.0} \mathrm{~kg} / \mathrm{ha}$ treatment, while minimum value (18.33 $\mathrm{g}$ in 2008-09 
and $23.83 \mathrm{~g}$ in 2009-10) noticed in control. Bulb yield is more important than total biological yield which results from different combinations of many physiological processes based on the environment under which the crop was grown. The maximum bulb yield (4.87 t/ha in 2008-09 and $6.6 \mathrm{t} / \mathrm{ha}$ in 2009-10) were recorded in $\mathrm{Zn}_{3.0} \mathrm{Cu}_{1.0} \mathrm{~B}_{3.0} \mathrm{Mo}_{1.0} \mathrm{~kg} / \mathrm{ha}$ treatment, while minimum bulb yield (2.3 t/ha in 2008-09 and 2.9 t/ha in 2009-10) were in control (Table 3).

Table 3. Effect of micronutrients yield and yield attributes of garlic

\begin{tabular}{|c|c|c|c|c|c|c|}
\hline \multirow[t]{2}{*}{ Treatment } & \multicolumn{2}{|c|}{ No. of Cloves per bulb } & \multicolumn{2}{|c|}{$\begin{array}{l}\text { Weight of single bulb } \\
(\mathrm{g})\end{array}$} & \multicolumn{2}{|c|}{$\begin{array}{l}\text { Yield of bulb } \\
\text { (t/ha) }\end{array}$} \\
\hline & 2008-09 & $2009-10$ & 2008-09 & $2009-10$ & 2008-09 & $2009-10$ \\
\hline $\mathrm{Zn}_{0} \mathrm{Cu}_{1.0} \mathrm{~B}_{2.0} \mathrm{Mo}_{1.0}$ & $30.23 \mathrm{~d}$ & $24.70 \mathrm{fg}$ & $22.27 \mathrm{de}$ & 26.87ef & $3.30 \mathrm{~d}$ & $3.3 \mathrm{fg}$ \\
\hline $\mathrm{Zn}_{1.0} \mathrm{Cu}_{1.0} \mathrm{~B}_{2.0} \mathrm{Mo}_{1.0}$ & $33.80 \mathrm{bcd}$ & $33.93 \mathrm{cde}$ & $22.83 \mathrm{cde}$ & $26.60 \mathrm{ef}$ & $3.57 \mathrm{~d}$ & $3.9 \mathrm{ef}$ \\
\hline $\mathrm{Zn}_{1.5} \mathrm{Cu}_{1.0} \mathrm{~B}_{2.0} \mathrm{Mo}_{1.0}$ & $35.53 \mathrm{abc}$ & $33.93 \mathrm{cde}$ & $24.47 b-e$ & $27.23 \mathrm{ef}$ & $4.17 b c$ & $4.2 \mathrm{de}$ \\
\hline $\mathrm{Zn}_{3.0} \mathrm{Cu}_{1.0} \mathrm{~B}_{2.0} \mathrm{Mo}_{1.0}$ & $39.47 \mathrm{a}$ & $42.60 \mathrm{ab}$ & $26.50 \mathrm{abc}$ & $38.27 \mathrm{ab}$ & 4.43abc & $6.4 \mathrm{a}$ \\
\hline $\mathrm{Zn}_{4.5} \mathrm{Cu}_{1.0} \mathrm{~B}_{2.0} \mathrm{Mo}_{1.0}$ & $37.37 \mathrm{ab}$ & $37.97 \mathrm{a}-\mathrm{d}$ & $24.93 \mathrm{bcd}$ & $31.00 \mathrm{cde}$ & $4.27 b c$ & $5.4 \mathrm{bc}$ \\
\hline $\mathrm{Zn}_{3.0} \mathrm{Cu}_{0} \mathrm{~B}_{2.0} \mathrm{Mo}_{1.0}$ & $34.27 \mathrm{bcd}$ & $37.20 \mathrm{~b}-\mathrm{e}$ & $22.27 \mathrm{de}$ & $32.27 \mathrm{~b}-\mathrm{e}$ & $3.40 \mathrm{~d}$ & $3.7 \mathrm{efg}$ \\
\hline $\mathrm{Zn}_{3.0} \mathrm{Cu}_{0.5} \mathrm{~B}_{2.0} \mathrm{Mo}_{1.0}$ & $39.77 \mathrm{a}$ & $38.63 a-d$ & $25.27 \mathrm{a}-\mathrm{d}$ & $29.23 \mathrm{def}$ & $4.10 \mathrm{c}$ & $4.8 \mathrm{~cd}$ \\
\hline $\mathrm{Zn}_{3.0} \mathrm{Cu}_{1.5} \mathrm{~B}_{2.0} \mathrm{Mo}_{1.0}$ & $36.50 \mathrm{a}$ & $40.00 \mathrm{a}-\mathrm{d}$ & $25.67 a-d$ & 33.30b-e & $4.67 \mathrm{ab}$ & $5.3 \mathrm{c}$ \\
\hline $\mathrm{Zn}_{3.0} \mathrm{Cu}_{1.0} \mathrm{~B}_{0} \mathrm{Mo}_{1.0}$ & $36.87 \mathrm{abc}$ & $29.40 \mathrm{ef}$ & $20.80 \mathrm{ef}$ & $28.27 \mathrm{ef}$ & $3.40 \mathrm{~d}$ & $4.1 \mathrm{def}$ \\
\hline $\mathrm{Zn}_{3.0} \mathrm{Cu}_{1.0} \mathrm{~B}_{1.0} \mathrm{Mo}_{1.0}$ & $39.57 \mathrm{a}$ & $43.37 \mathrm{ab}$ & $24.87 \mathrm{bcd}$ & $35.03 \mathrm{bcd}$ & $4.47 \mathrm{ab}$ & $5.5 \mathrm{bc}$ \\
\hline $\mathrm{Zn}_{3.0} \mathrm{Cu}_{1.0} \mathrm{~B}_{3.0} \mathrm{Mo}_{1.0}$ & $40.37 \mathrm{a}$ & $45.37 \mathrm{a}$ & $28.93 a$ & $41.70 \mathrm{a}$ & $4.87 \mathrm{a}$ & $6.6 a$ \\
\hline $\mathrm{Zn}_{3.0} \mathrm{Cu}_{1.0} \mathrm{~B}_{2.0} \mathrm{Mo}_{0}$ & $32.57 \mathrm{~cd}$ & $33.07 \mathrm{de}$ & $23.50 \mathrm{cde}$ & 29.30def & $3.30 \mathrm{~d}$ & $3.7 \mathrm{efg}$ \\
\hline $\mathrm{Zn}_{3.0} \mathrm{Cu}_{1.0} \mathrm{~B}_{2.0} \mathrm{Mo}_{0.5}$ & $40.37 \mathrm{a}$ & $41.50 \mathrm{abc}$ & $27.90 \mathrm{ab}$ & $36.53 \mathrm{abc}$ & $4.57 \mathrm{abc}$ & $6.2 \mathrm{ab}$ \\
\hline $\mathrm{Zn}_{0} \mathrm{Cu}_{0} \mathrm{~B}_{0} \mathrm{Mo}_{0}$ & $20.07 \mathrm{e}$ & $21.13 \mathrm{~g}$ & $18.33 \mathrm{f}$ & $23.83 \mathrm{f}$ & $2.30 \mathrm{e}$ & $2.9 \mathrm{~g}$ \\
\hline CV $(\%)$ & 6.99 & 11.86 & 8.17 & 10.75 & 6.99 & 9.71 \\
\hline
\end{tabular}

Treatment means having common letter(s) are not significantly different from each other at $5 \%$ level of probability by DMRT.

The improvement on growth and yield of garlic might be due to the enhanced enzymatic and photosynthetic activity and greater translocation rate due to the influence of micronutrients. The entire favorable effect was also attributed to the fact that the micronutrients were essential in better absorption of water, macronutrients uptake and metabolism. The higher bulb yield of garlic may be attributed to improved growth parameters and yield components which ultimately resulted in higher bulb yield and also due to the supply of micronutrients and indirectly the physical condition of soil viz., aggregation, aeration, permeability, water holding capacity and biological condition of soil, which resulted in significantly higher bulb yield of garlic. 


\section{Conclusion}

Zinc, copper, boron and molybdenum played an important role in increasing growth and bulb yield of garlic. The fertilizer treatment $\mathrm{Zn}_{3.0} \mathrm{Cu}_{1.0} \mathrm{~B}_{3.0} \mathrm{Mo}_{1.0} \mathrm{~kg} / \mathrm{ha}$ was found to be the best suitable dose for garlic cultivation in Grey Terrace Soil of Amnura Soil Series under AEZ-25 (Level Barind Tract) of Bangladesh.

\section{References}

Balch, P. A. 2000. Prescription for Nutritional Healing, $3^{\text {rd }}$ Ed. New York: Avery. P. 97.

Durak, I., Kavutch, M., Aytac, B., et al. 2004. Effects of garlic extract consumption on blood lipid and oxidant/antioxidant parameters in humans with high blood cholesterol. J. Nutr. Biochem. Jun. 15(6):373-377.

Chanchan, M., J.K. Hore and S. Ghanti.2013. Response of garlic to foliar application of some micronutrients. J. crop and Weed. 9(2):138-141.

Gomez, K.A. and A.A. Gomez. 1984. Statistical Procedures for Agricultural Research. John Wiley and Sons Inc., New York. P. 214.

Gupta, N.K. and R/K. Ganeshe. 2000. Response of borax and zinc sulphate on growth and yield of garlic (Allium sativum L.). Adv. Pl. Sci.13:237-239.

Jermsiri, J., H. Watanabe, S. Addhajarusith and J. Tantivoravith. 1995. Effects of boron on growth of garlic. Thai Agril. Sci. 28(1-3):25-38. (In Thai with English abstract).

Katzer, G. 2005. Spices Pages: Garlic (Allium sativum, garlic).

Purseglove, J.W. 1987. Tropical crops dicotyledons. Longman, Singapore publishers (Pvt.) Ltd.

Selvaraj, N, S, Natarajan, V.M, Selvarajan, S. Mathews and A. Pabitha. 2002. Effect of foliar application of micronutrients on the growth and yield of garlic. S. Ind. Hort., 50:159-168.

Srivastava, R, A. Agarwal, R.S. Tiwari and S. Kumar, 2005. Effect of micronutrients, zinc and boron on yield, quality and storability of garlic (Allium sativum). Ind. J. Agril. Sci.,75: 157-159. 